\title{
Factors Relating to the Incidence of Obesity in Women of Reproductive Age in the Working Area of the Community Health Center of Suak Ribee of Johan Pahlawan District of West Aceh Regency
}

\author{
${ }^{1}$ Fitriani Fitriani, ${ }^{1}$ Teungkunih Farisni, ${ }^{1}$ Yarmaliza Yarmaliza, ${ }^{1}$ Pipi Rahayu \\ Study Program of Public Health Science, Faculty of Public Health, Teuku Umar University, \\ Aceh, Indonesia \\ Corresponding author's email: fitriani@utu.ac.id
}

Submitted: 23/08/2019 Revised: 29/09/2019 Accepted: 04/10/2019

How to cite this article:

Fitriani, F., Farisni, T., Yarmaliza, Y., \& Rahayu, P. (2019). Factors relating to the incidence of obesity in women of reproductive age in the working area of the community health center of

Suak Ribee of Johan Pahlawan District of West Aceh Regency. J-KESMAS, 6(2), 74 -

\begin{abstract}
Obesity is a serious condition that can cause emotional and social problems. A person is considered overweight if his weight is $10 \%$ to $20 \%$ over his ideal body weight, while obesity occurs when a person has more than $20 \%$ over his ideal body weight. The working area of the Community Health Center (Puskesmas) of SuakRibeewas the area with the highest incidence of obesity in West Aceh with 89 cases. This study aims to find out the relationship between the incidenceof obesity and the factor of knowledge, diet, physical activity, family history of obesity, and occupation. This study is an analytical study with cross-sectional design. The sample in this study was all women of reproductive age in the working area ofPuskesmas of SuakRibee of Johan Pahlawan District of West Aceh Regency. The sample was taken using cluster sampling method, with a total of 98 people. The data analysis technique used was correlation test. Based on the results of the correlation test,it can be concluded that there was no relationship between the incidence of obesity and knowledge (p-value $=0.113>\alpha=$ 0.05 ). However, there was a relationship between the incidence of obesity and diet ( $\mathrm{p}$-value $=$ $0.030<\alpha=0.05$ ); physical activity ( $\mathrm{p}$-value $=0.021<\alpha=0.05$ ); family history of obesity (pvalue $=0.034<\alpha=0.05$ ); and occupation ( $\mathrm{p}$-value $=0.000<\alpha=0.05$ ).
\end{abstract}

\section{Keywords}

Knowledge; diet, physical activity; family history of obesity; occupation; incidence of obesity 


\section{Introduction}

Obesity is a serious condition that can cause emotional and social problems. A person is considered overweight if his weight is $10 \%$ to $20 \%$ over his ideal body weight, while obesity occurs when a person has more than $20 \%$ over his ideal body weight. Obesity is currently a global problem, even the World Health Organization (WHO) declares it a global epidemic (Riswanti \& Bambang 2017).

According to WHO (2015), more than 1.9 billion adults in 2014 were overweight. More than 600 million out of these people were obese. Overall in 2014, around $13 \%$ of the world's adult population was obese while $39 \%$ of the world's adult population was overweight.

The increased prevalence of obesity does not only happen in developed countries, but also in developing countries like Indonesia. According to the results of Indonesia Basic Health Research (Riskerdas) 2018, the proportion of overweight and obesity in adults over 18 years increased from 2007-2018, where the number of overweight adults in 2007 was 8.6\%, 2013 $(11.5 \%)$, and $2018(13.6 \%)$. On the othe hand, the number of adults with obesity in 2007 was $10.5 \%, 2013(14.8 \%)$, and $2018(21.8 \%)$. The lowestprevalence of adult obesity was in East Nusa Tenggara Province (10.3\%) and the highest was in North Sulawesi $(30.2 \%)$. Aceh itself was included in the sixteen provinces with a prevalence above the national level $(15.4 \%)$.

The sixteen provinces with a prevalence of obesity above national level areBanten, East Java, West Java, Bali, Bangka Belitung, Riau, Aceh, Gorontalo, North Maluku, North Sumatra, North Kalimantan, Riau Islands, West Papua, East Kalimantan, DKI Jakarta, and North Sulawesi (Ministry of Health of the Republic of Indonesia, 2013).

Based on the survey data for the monitoring of the nutritional status of Aceh Province in 2017 ,there was a sizeable prevalence of overweight and obesity in the population aged 18-60 referring to the Body Mass Index (BMI), with a total of 52.4\%. The highest proportion of this number went to obesity with $36.4 \%$. The highest proportion of obesity in Aceh was in BenerMeriah (45.5\%) and Sabang City (43.4\%), while the lowest was in Simeulue (23.6\%) and Pidie $(29.6 \%)$. Furthermore, considering the sex factor, it was seen that the percentage of the adult male population who were obese was $12.2 \%$, while the percentage of the adult female population who were obese was 37.3\% (Aceh Provincial Health Office, 2017).

Based on data from the West Aceh Regency Health Office in 2017, there were 43 cases of obesity in women aged 15-44, with the distribution ofthe cases was Puskesmas ofMeureubowith one case and Puskesmas of SuakRibeewith 42 cases. Whereas in 2018, these cases increased to 119 cases, with the distribution of the cases was Puskesmas ofMeureubowith 30 cases and Puskesmas of SuakRibee 89 cases (West Aceh Regency Health Office, 2019).

The increased prevalence of obesity occurs due to lack of physical activity and changes in diet. Physical activity is the main key for energy balance which contributes to energy expenditure (Musa, 2010).The modern lifestyle makes the body rarely moves or uses less energy for daily activities. Meanwhile, the food consumed needs to be burned so that it will not accumulate into fat (Dewi, 2011).

Women in reproductive age are those who are in the age between 15-49 years old and women at this age still have the potential to give birth. For women, lack of physical activity greatly affects their health, especially when they have more food intake, which will cause fat accumulation and result in obesity (Hasan, 2014). 


\section{Method}

This study used a quantitative research design with a cross sectional approach which was conducted in the workingarea of Puskesmas of Suak Ribee of Johan Pahlawan District of West Aceh Regency on May 22-June 16, 2019. The population in this study was all women of reproductive age and the number of the sample was 98 people. The data analysis used was univariate, bivariate and correlation analysis.

\section{Results and Discussion}

Table 1. the Analysis of the Correlation between Knowledge and Incidence of Obesity in Women of Reproductive Age in the Working Area of Puskesmas of Suak Ribee of Johan Pahlawan District of West Aceh Regency.

\begin{tabular}{|c|c|c|c|}
\hline Variable & $\begin{array}{c}\text { Pearson } \\
\text { Correlation }\end{array}$ & Sig. (2-tailed) & N \\
\hline Knowledge & -0.161 & 0.113 & 98 \\
\hline
\end{tabular}

Source : Primary Data (analyzed) in 2019

Based on the result of the univariate analysis, it was found that from the 98 respondents, 45 respondents $(45.9 \%)$ had good knowledge and53 respondents $(54.1 \%)$ had poor knowledge.

The correlation coefficient was used to determine the level of significance of the relationship between the studied variable (knowledge) as the independent variable and the incidence of obesity as the dependent variable.Partially, the independent variable (knowledge) was not related to the dependent variable (incidence of obesity) with a weak correlation as indicated by the significant value of $0.113>0.05$ and the Pearson correlation value of -0.161 .

Table 2. The Analysis of the Correlation between Diet and Incidence of Obesity in Women of Reproductive Age in the Working Area of Puskesmas of Suak Ribee of Johan Pahlawan District of West Aceh Regency.

\begin{tabular}{|c|c|c|c|}
\hline Variable & $\begin{array}{c}\text { Pearson } \\
\text { Correlation }\end{array}$ & Sig. (2-tailed) & $\mathbf{N}$ \\
\hline Diet & -0.219 & 0.030 & 98 \\
\hline
\end{tabular}

Source: Primary Data (analyzed) in 2019

Based on the result of the univariate analysis, it was found that from the 98 respondents, 46 respondents $(46.9 \%)$ had a good dietand52 respondents $(53.1 \%)$ had a bad diet.

The correlation coefficient was used to determine the level of significance of the relationship between the studied variable (diet) as the independent variable and the incidence of obesity as the dependent variable.Partially, the independent variable (diet) was related to the dependent variable (incidence of obesity) with a weak correlation as indicated by the significant value of $0.030<0.05$ and the Pearson correlation value of 0.219 . 
Table 3. The Analysis of the Correlation between Physical Activity and Incidence of Obesity in Women of Reproductive Age in the Working Area of Puskesmas of Suak Ribee of Johan Pahlawan District of West Aceh Regency.

\begin{tabular}{|c|c|c|c|}
\hline Variable & $\begin{array}{c}\text { Pearson } \\
\text { Correlation }\end{array}$ & Sig. (2-tailed) & N \\
\hline Physical Activity & 0.232 & 0.021 & 98 \\
\hline
\end{tabular}

Source : Primary Data (analyzed) in 2019

Based on the result of the univariate analysis, it was found that from the 98 respondents, 42 respondents $(42.9 \%)$ had enoughphysical activitiesand56 respondents $(57.1 \%)$ had no physical activities.

The correlation coefficient was used to determine the level of significance of the relationship between the studied variable (physical activity) as the independent variable and the incidence of obesity as the dependent variable.Partially, the independent variable (physical activity) was related to the dependent variable (incidence of obesity) with a weak correlation as indicated by the significant value of $0.021<0.05$ and the Pearson correlation value of 0.232 .

Table 4. The Analysis of the Correlation between Family History of Obesity and Incidence of Obesity in Women of Reproductive Age in the Working Area of Puskesmas of Suak Ribee of Johan Pahlawan District of West Aceh Regency.

\begin{tabular}{|c|c|c|c|}
\hline Variable & $\begin{array}{c}\text { Pearson } \\
\text { Correlation }\end{array}$ & Sig. (2-tailed) & $\mathbf{N}$ \\
\hline Family History of Obesity & 0.215 & 0.034 & 98 \\
\hline
\end{tabular}

Source : Primary Data (analyzed) in 2019.

Based on the result of the univariate analysis, it was found that from the 98 respondents, 62 respondents $(63.3 \%)$ had family history of obesityand 36 respondents $(36.7 \%)$ had no family history of obesity.

The correlation coefficient was used to determine the level of significance of the relationship between the studied variable (family history of obesity) as the independent variable and the incidence of obesity as the dependent variable.Partially, the independent variable (family history of obesity) was related to the dependent variable (incidence of obesity) with a weak correlation as indicated by the significant value of $0.034<0.05$ and the Pearson correlation value of 0.215 .

Table 5. The Analysis of the Correlation between Occupation and Incidence of Obesity in Women of Reproductive Age in the Working Area of Puskesmas of Suak Ribee of Johan Pahlawan District of West Aceh Regency

\begin{tabular}{|c|c|c|c|}
\hline Variable & $\begin{array}{c}\text { Pearson } \\
\text { Correlation }\end{array}$ & Sig. (2-tailed) & $\mathbf{N}$ \\
\hline Occupation & -0.427 & 0.000 & 98 \\
\hline
\end{tabular}

Source : Primary Data (analyzed) in 2019.

Based on the result of the univariate analysis, it was found that from the 98 respondents, 42 respondents (42.9\%)had workand56 respondents $(57.1 \%)$ had no work. 
The correlation coefficient was used to determine the level of significance of the relationship between the studied variable (occupation) as the independent variable and the incidence of obesity as the dependent variable.Partially, the independent variable (occupation) was related to the dependent variable (incidence of obesity) with a moderate correlation as indicated by the significant value of $0.000<0.05$ and the Pearson correlation value of -0.427 .

\section{Conclusion}

1. There was no significant relationship between knowledge and the incidence of obesity in women of reproductive age in the work area of SuakRibee Health Center of Johan Pahlawan District of West Aceh Regency.

2. There was significant relationship between diet and the incidence of obesity in women of reproductive age in the work area of SuakRibeeHealth Center of Johan Pahlawan District of West Aceh Regency.

3. There was significant relationship between physical activity and the incidence of obesity in women of reproductive age in the work area of SuakRibee Health Center of Johan Pahlawan District of West Aceh Regency.

4. There was significant relationship between family history of obesity and the incidence of obesity in women of reproductive age in the work area of SuakRibee Health Center of Johan Pahlawan District of West Aceh Regency.

5. There was significant relationship between occupation and the incidence of obesity in women of reproductive age in the work area of SuakRibee Health Center of Johan Pahlawan District of West Aceh Regency.

\section{References}

Alfridsyah, et al. 2017. Survay Pemantauan Status Gizi Provinsi Aceh 2017 [Survey of the Monitoring of the Nutritional Status of Aceh Province in 2017], First Edition. Banda Aceh: Dinkes Aceh dan Jurusan Gizi Poltekes Kemenkes Aceh.

Balitbangkes. Riset Kesehatan Dasar2018 [Basic Health Research of 2018]. Badan Penelitian dan Pengembangan Kesehatan Kementerian Kesehatan RI: 2018.

Dewi, L. (2011). Pola Makan Sehat dan Gaya Hidup yang Benar [Healthy Diet and Lifestyle]. Retrieved from http://www.rumahsakitmitrakemayoran.com

Dinas Kesehatan. 2019. Surveilans Penyakit Tidak Menular Berbasis Puskesmas (Prevalensi) [Non-communicable Disease Surveillance Based on Community Health Center (Prevalence)]. Dinkes Aceh Barat.

Kementerian Kesehatan RI. 2013. Riset Kesehatan Dasar Tahun 2013[Basic Health Research of 2013]. Jakarta. Badan Penelitian dan Pengembangan Kesehatan Kementerian Kesehatan RI. Retrieved from http://www.depkes.go.id/resources/download/general/Hasil\%20Riskesdas\%20201 3.pdf.

Kementrian Kesehatan RI. Buku saku pemantauan Status Gizi dan Indikator Kinerja Gizi tahun 2017 [Nutritional Status Monitoring Handbook and Performance Indicators of 2017]. Kemenkes, Jakarta, 2018.

Musa. (2010). Faktor Risiko Obesitas Pada Remaja [Risk Factors of Obesity in Teenagers]. Retrieved from http://www.dik.undip.ac.id 
Riswanti \& Bambang. 2017. Pola Konsumsi Fast Food, Aktivitas Fisik dan Faktor Keturunan Terhadap Kejadian Obesitas (Studi Kasus pada Siswa SD Negeri 01 Tonjong Kecamatan Tonjong Kabupaten Brebes)[Fast Food Consumption Pattern, Physical Activity, and Heredity Factors Against Obesity (A Case Study in Students of State Elementary School 01 of Tonjong of Tonjong District of Brebes Regency)]. The Journal Public Health Perspective Vol. 2, No. 3, (2017), Universitas Negeri Semarang, Indonesia. Retrieved onMarch 01, 2019 fromhttps://journal.unnes.ac.id/nju/index.php/phpj/article/view/13774

WHO. 2015. Obesity and Overweight. Retrieved from http://www.who.int/mediacentre/factsheets/fs311/en 